\title{
Analisis Tingkat Pelayanan Trans Balikpapan Berdasarkan Persepsi Pengguna (Studi Kasus: Koridor D Terminal Batu Ampar-Pelabuhan Ferry Kariangau)
}

\author{
Zahra Salsabila, Ajeng Nugrahaning Dewanti dan Mohtana Kharisma Kadri \\ Institut Teknologi Kalimantan \\ e-mail:08161091@student.itk.ac.id
}

\begin{abstract}
Abstrak - Trans Balikpapan merupakan satu-satunya transportasi umum di Kota Balikpapan yang melayani mobilitas penduduk dari Terminal Batu Ampar-Pelabuhan Ferry Kariangau. Akan tetapi terdapat beberapa aspek pelayanan Trans Balikpapan yang tidak sesuai dengan standar pelayanan minimal, diantaranya adalah keselamatan, kenyamanan, kesetaraan dan keteraturan. Di sisi lain terjadi penurunan jumlah pengguna Trans Balikpapan pada tahun 2014-2019. Dengan melakukan analisis tingkat pelayanan dapat diketahui tingkat kinerja dan kepentingan dari setiap faktor kualitas pelayanan maupun secara keseluruhan, sehingga dapat menjadi masukan dalam peningkatan pelayanan. Berdasarkan hasil analisis Importance Performance Analysis (IPA) diketahui bahwa secara rata-rata keseluruhan, pelayanan Trans Balikpapan termasuk dalam kategori kurang puas menurut penumpang dengan nilai $76 \%$ serta terdapat beberapa variabel yang memiliki kinerja rendah namun tergolong penting menurut penumpang yaitu kursi prioritas, fasilitas kebersihan halte, fasilitas kebersihan bus, ketepatan waktu, informasi tarif, informasi jadwal, ruang khusus untuk kursi roda dan waktu tunggu.
\end{abstract}

Kata Kunci- Kualitas Pelayanan, Tingkat Kepentingan, Tingkat Kinerja, Trans Balikpapan.

\section{PENDAHULUAN}

$\mathrm{T}$ rans Balikpapan merupakan satu-satunya transportasi umum di Kota Balikpapan yang melayani mobilitas penduduk melalui Jl. Soekarno Hatta Km 5,5 hingga Jl. Projakal adalah Trans Balikpapan Koridor D Terminal Batu Ampar-Pelabuhan Ferry Kariangau [1]. Akan tetapi terdapat beberapa aspek pelayanan Trans Balikpapan yang tidak sesuai dengan standar pelayanan minimal angkutan massal berbasis jalan [2], yang terdiri dari aspek keselamatan, kenyamanan, kesetaraan, keteraturan. Rata-rata jumlah penumpang harian Trans Balikpapan pada tahun 2014 sebesar 100 jiwa dalam satu hari dan jumlahnya menurun pada tahun 2019 yang hanya sebesar 75 jiwa. Jumlah armada bus Trans Balikpapan sejak awal dioperasikan tahun 2014 hingga saat ini pun cenderung tetap, yaitu sebanyak 4 armada yang melayani Koridor D, dimana hal ini menandakan bahwa peminat Trans Balikpapan cenderung tetap atau tidak bertambah [1][3][4].

Rendahnya peranan angkutan umum dalam melayani masyarakat disebabkan oleh rendahnya tingkat pelayanan angkutan umum itu sendiri, sehingga menyebabkan peningkatan jumlah kendaraan pribadi [5]. Jika pelayanan angkutan umum yang rendah tidak diperbaiki maka pengguna jasa transportasi semakin enggan menggunakan transportasi umum dan penggunanya akan semakin berkurang [6].

Berdasarkan pemaparan sebelumnya maka perlu melakukan analisis tingkat pelayanan Trans Balikpapan berdasarkan persepsi pengguna (Studi Kasus: Koridor D Terminal Batu Ampar-Pelabuhan Ferry Kariangau). Dengan melakukan analisis tingkat pelayanan berdasarkan persepsi pengguna maka dapat diketahui tingkat kinerja dan kepentingan dari setiap faktor kualitas pelayanan maupun secara keseluruhan menurut persepsi penumpang Trans Balikpapan. Berdasarkan analisis tersebut dapat menjadi masukan dalam melaksanakan peningkatan pelayanan Trans Balikpapan Koridor D, mengingat koridor ini sebagai satu-satunya koridor yang beroperasi sejak tahun 2014 [1].

\section{METODE PENELITIAN}

\section{A. Variabel Penelitian}

Berdasarkan tinjauan pustaka dan penelitian terdahulu, didapatkan 25 variabel yang digunakan dalam penelitian ini sebagaimana yang tercantum dalam Tabel 1

\section{B. Populasi dan Sampel}

Dalam menganalisis tingkat pelayanan Trans Balikapapan berdasarkan persepsi penumpang, populasinya yaitu penumpang Trans Balikpapan sebanyak 20.400 penumpang pada tahun 2019 [1]. Menggunakan rumus Slovin dengan tingkat ketelitian $10 \%$ didapatkan sampel pengguna Trans Balikpapan sebanyak 100 orang [6].

\section{Metode Pengumpulan Data}

Data mengenai tingkat pelayanan Trans Balikpapan berdasarkan persepsi penumpang didapatkan melalui penyebaran kuisioner kepada 100 pengguna Trans Balikpapan. Adapun kuisioner untuk menilai tingkat kinerja dan kepentingan menggunakan modifikasi skala likert yang terdiri dari 4 jawaban [9]. Modifikasi skala likert dilakukan untuk meniadakan kategori cukup yang tidak condong kepada jawaban buruk atau baik [10]. Penilaian yang digunakan untuk mengukur tingkat kinerja dan kepentingan tercantum dalam Tabel 2. 
Tabel 1.

Faktor dan Variabel Kualitas Pelayanan Trans Balikpapan

\begin{tabular}{|c|c|}
\hline Faktor & $\begin{array}{c}\text { Variabel } \\
\end{array}$ \\
\hline \multirow[t]{7}{*}{ Kenyamanan } & Kenyamanan tempat duduk bus \\
\hline & Kapasitas bus \\
\hline & Fasilitas pengatur suhu ruangan bus \\
\hline & Fasilitas kebersihan bus \\
\hline & Luas lantai per orang halte \\
\hline & Fasilitas kebersihan halte \\
\hline & $\begin{array}{l}\text { Fasilitas kemudahan naik/ turun } \\
\text { kendaraan }\end{array}$ \\
\hline \multirow[t]{4}{*}{ Keselamatan } & Keselamatan di tempat pemberhentian \\
\hline & Kelaikan kendaraan \\
\hline & Peralatan keselamatan \\
\hline & Fasilitas pegangan bagi penumpang berdiri \\
\hline Empati & Ketersediaan Layanan Pengaduan \\
\hline \multirow[t]{4}{*}{ Keamanan } & Identitas kendaraan \\
\hline & Tanda pengenal pengemudi \\
\hline & Petugas keamanan bus \\
\hline & Petugas keamanan halte \\
\hline \multirow[t]{2}{*}{ Keterjangkauan } & Integrasi jaringan trayek pengumpan \\
\hline & Tarif \\
\hline \multirow[t]{3}{*}{ Kesetaraan } & Kursi prioritas \\
\hline & Ruang khusus untuk kursi roda \\
\hline & Kemiringan lantai dan tekstur khusus \\
\hline \multirow[t]{5}{*}{ Keteraturan } & Waktu tunggu \\
\hline & Kecepatan perjalanan \\
\hline & Informasi pelayanan \\
\hline & Informasi gangguan perjalanan bus \\
\hline & $\begin{array}{l}\text { Ketepatan dan kepastian jadwal } \\
\text { keberangkatan dan kedatangan bus }\end{array}$ \\
\hline \multirow[t]{2}{*}{ Tangible } & Kerapian petugas \\
\hline & Fasilitas kursi di tiap halte tersedia \\
\hline \multicolumn{2}{|c|}{$\begin{array}{c}\text { Iabel } 2 . \\
\text { Skala Tingkat Kinerja dan Kepentingan } \\
\end{array}$} \\
\hline \multicolumn{2}{|c|}{$\begin{array}{cc}\text { Tingkat Kepentingan } & \text { Tingkat Kinerja } \\
\end{array}$} \\
\hline Sangat Tidak Penting & Sangat Tidak Baik \\
\hline Tidak Penting & Tidak Baik \\
\hline Penting & Baik \\
\hline Sangat Pen & Sangat Baik \\
\hline
\end{tabular}

\section{Metode Analisis Data}

Penelitian ini menggunakan metode Importance Performance Analysis (IPA) untuk menilai tingkat kepentingan dan kinerja pelayanan Trans Balikpapan. Terdapat beberapa tahapan analisis IPA, yang terdiri dari [8][9]:

1. Menghitung Tingkat Kesesuaian

$$
\mathrm{Tki}=\mathrm{Xi} / \mathrm{Yi} \times 100 \%
$$

Keterangan:

Tki : Tingkat kesesuaian

$\mathrm{Xi}$ : Total skor kinerja variabel ke i

Yi : Total skor kepentingan variabel ke i

Kepuasan merupakan perbandingan kinerja yang dirasakan dengan harapan, sehingga jika kinerja dibawah harapan maka pelanggan akan kecewa dan jika kinerja sesuai dengan harapan maka pelanggan akan puas dan jika kinerja melebihi harapan maka pelanggan akan sangat puas [9]. Kategorisasi tingkat kepuasan dikelompokkan menjadi empat kategori, yaitu sangat puas, puas, tidak puas dan sangat tidak puas. Dalam menentukan kriteria skor maka digunakan kriteria Patokan Acuan Norma (PAN) dalam skala empat dengan rumus sebagai berikut:

1. $(\mathrm{Xi}+1,5 \mathrm{SDi})<(\mathrm{Xi}+3 \mathrm{SDi})=$ Sangat Puas

2. $\mathrm{Xi}<(\mathrm{Xi}+1,5 \mathrm{SDi})=$ Puas

3. $(\mathrm{Xi}-1,5 \mathrm{SDi})<\mathrm{Xi}=$ Tidak Puas

4. $(\mathrm{Xi}-3 \mathrm{SDi})<(\mathrm{Xi}-1,5 \mathrm{SDi})=$ Sangat Tidak Puas

Keterangan:

$\mathrm{Xi}=$ Mean(rerata) ideal =1/2 (Maksimum ideal + Minimal ideal).

$\mathrm{SDi}=$ Standar deviasi ideal $=1 / 6($ Maksimum ideal - Minimal ideal $)$

2. Menghitung rata-rata kinerja dan kepentingan setiap variabel

Keterangan:

$$
\begin{aligned}
& \mathrm{Xi} \text { rata }- \text { rata }=\Sigma \mathrm{Xi} / \mathrm{n} \\
& \mathrm{Yi} \text { rata }- \text { rata }=\Sigma \mathrm{Yi} / \mathrm{n}
\end{aligned}
$$

$\mathrm{Xi}$ : Total skor kinerja variabel ke i

$\mathrm{Yi} \quad$ : Total Skor kepentingan variabel ke i

$\mathrm{n}$ : Jumlah data

3. Menghitung rata-rata kinerja dan kepentingan seluruh variable

Xi rata - rata seluruh variabel $=\sum X i$ rata - rata $/ k(4)$

Yi rata - rata seluruh variabel $=\sum$ Yi rata - rata $/ \mathrm{k}(5)$ Keterangan:

$\mathrm{k}$ : Jumlah variabel

4. Pemetaan Kuadran

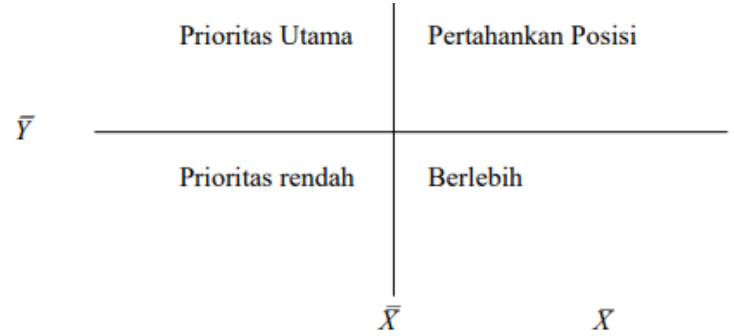

Gambar 1. Diagram Kartesius [9]

a. Kuadran I (Prioritas Utama)

Pada kuadran ini memuat atribut yang dianggap penting namun kinerjanya belum sesuai dengan yang diharapkan oleh pengguna jasa. Atribut-atribut yang termasuk dalam kuadran ini menjadi prioritas dalam peningkatan kinerja.

b. Kuadran II (Pertahankan Posisi)

Pada kuadran ini memuat atribut yang dianggap penting oleh pengguna jasa dan memiliki kinerja yang sesuai dengan yang diharapkan oleh pengguna jasa. Atribut-atribut yang masuk dalam kuadran ini harus dipertahankan kinerjanya karena memiliki tingkat kepentingan yang besar dan kinerja yang baik. c. Kuadran III (Prioritas Rendah)

Pada kuadran ini memuat atribut yang dirasa kurang penting dan kinerjanya tidak sesuai dengan harapan pengguna. Atribut-atribut yang masuk dalam kuadran ini perlu dipertimbangkan dalam peningkatan kinerjanya karena manfaat yang diperoleh oleh pengguna jasa tergolong kecil.

d. Kuadran IV (Berlebihan)

Pada kuadran ini memuat atribut-atribut yang dianggap kurang penting oleh pengguna jasa namun kinerjanya sesuai dengan harapan pengguna, sehingga dianggap berlebihan. 


\section{HASIL DAN DISKUSI}

\section{A. Karakteristik Wilayah Studi}

Penelitian ini memiliki fokus pada satu-satunya koridor Trans Balikpapan yang beroperasi, yaitu Koridor D Terminal Batu Ampar-Pelabuhan Ferry Kariangau.

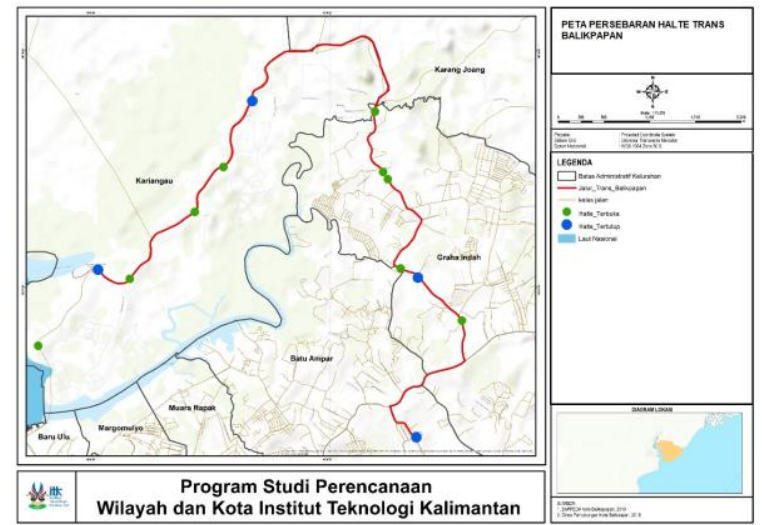

Gambar 2. Peta Rute Pelayanan dan Persebaran Halte Trans Balikpapan Koridor D Terminal Batu Ampar-Pelabuhan Ferry Kariangau [1]

\section{B. Karakteristik Kualitas Pelayanan Trans Balikpapan}

Karakteristik kualitas pelayanan meliputi kondisi eksisting dari variabel kualitas pelayanan Trans Balikpapan. Kondisi eksisting variabel kualitas pelayanan ini dinilai berdasarkan pendapat responden penelitian yang diubah ke dalam bentuk skala likert. Jumlah penilaian kepentingan dan kinerja pelayanan Trans Balikpapan berdasarkan pendapat responden dapat dilihat pada Tabel 3.

\section{Tingkat Kesesuaian Pelayanan Trans Balikpapan}

Sebelum melakukan perhitungan tingkat kesesuaian, pertama-tama yaitu menentukan kategorisasi tingkat kepuasan. Diketahui bahwa nilai maksimum skor adalah $400 \%$ dan nilai minimum skor adalah $25 \%$, sehingga didapatkan nilai rata-rata ideal (Xi) yaitu $213 \%$ dan standar deviasi ideal sebesar $63 \%$. Sehingga didapatkan kriteria kategori skor sangat puas, puas, tidak puas dan sangat tidak puas sebagaimana yang tercantum dalam Tabel 4.

Tabel 4.

Kategorisasi Skor Tingkat Kepuasan

\begin{tabular}{cl}
\hline \multicolumn{2}{c}{ Kategorisasi Skor Tingkat Kepuasan } \\
\hline $306 \%-400 \%$ & \multicolumn{1}{c}{ Kategori } \\
$213 \%-305 \%$ & Puas Puas \\
$119 \%-212 \%$ & Tidak Puas \\
$25 \%-118 \%$ & Sangat Tidak Puas
\end{tabular}

Selanjutnya dilakukan perhitungan tingkat kesesuaian beserta kategorisasi tingkat kepuasan, sehingga didapatkan nilai untuk setiap variabel maupun secara keseluruhan sebagaimana tercantum dalam Tabel 5.

Berdasarkan tabel tersebut diketahui bahwa secara keseluruhan pelayanan Trans Balikpapan termasuk dalam kategori sangat tidak puas dengan nilai Sebesar 76\%. Terdapat 25 variabel dari 8 faktor yang termasuk dalam kategori sangat tidak puas dan terdapat 1 variabel dari 1 faktor yang termasuk dalam kategori tidak puas.

Tabel 3.

Jumlah Nilai Karakteristik Pelayanan Trans Balikpapan

\begin{tabular}{|c|c|c|c|}
\hline \multirow[t]{2}{*}{ Faktor } & \multirow[t]{2}{*}{ Variabel } & \multicolumn{2}{|c|}{ Jumlah } \\
\hline & & Kinerja (Xi) & $\begin{array}{c}\text { Kepentingan } \\
\text { (Yi) }\end{array}$ \\
\hline \multirow[t]{7}{*}{$\begin{array}{l}\text { Kenyam } \\
\text { anan }\end{array}$} & $\begin{array}{l}\text { Kenyamanan tempat } \\
\text { duduk bus }\end{array}$ & 400 & 356 \\
\hline & Kapasitas bus & 390 & 352 \\
\hline & $\begin{array}{l}\text { Fasilitas pengatur } \\
\text { suhu ruangan bus }\end{array}$ & 200 & 367 \\
\hline & $\begin{array}{l}\text { Fasilitas kebersihan } \\
\text { bus }\end{array}$ & 392 & 333 \\
\hline & $\begin{array}{l}\text { Luas lantai per orang } \\
\text { halte }\end{array}$ & 100 & 366 \\
\hline & $\begin{array}{l}\text { Fasilitas kebersihan } \\
\text { halte }\end{array}$ & 400 & 347 \\
\hline & $\begin{array}{l}\text { Fasilitas kemudahan } \\
\text { naik/ turun } \\
\text { kendaraan }\end{array}$ & 276 & 362 \\
\hline \multirow[t]{4}{*}{$\begin{array}{l}\text { Keselam } \\
\text { atan }\end{array}$} & $\begin{array}{l}\text { Keselamatan di } \\
\text { tempat } \\
\text { pemberhentian }\end{array}$ & 354 & 355 \\
\hline & Kelaikan kendaraan & 310 & 356 \\
\hline & $\begin{array}{l}\text { Peralatan } \\
\text { keselamatan }\end{array}$ & 332 & 358 \\
\hline & $\begin{array}{lr}\text { Fasilitas pegangan } \\
\text { bagi } \\
\text { berdiri }\end{array}$ & 100 & 339 \\
\hline Empati & $\begin{array}{l}\text { Ketersediaan } \\
\text { Layanan Pengaduan }\end{array}$ & 400 & 359 \\
\hline \multirow{4}{*}{$\begin{array}{l}\text { Keama } \\
\text { nan }\end{array}$} & Identitas kendaraan & 100 & 333 \\
\hline & $\begin{array}{l}\text { Tanda pengenal } \\
\text { pengemudi }\end{array}$ & 200 & 341 \\
\hline & $\begin{array}{l}\text { Petugas keamanan } \\
\text { bus }\end{array}$ & 146 & 350 \\
\hline & $\begin{array}{l}\text { Petugas keamanan } \\
\text { halte }\end{array}$ & 356 & 354 \\
\hline \multirow[t]{2}{*}{$\begin{array}{l}\text { Keterjan } \\
\text { gkauan }\end{array}$} & $\begin{array}{l}\text { Integrasi jaringan } \\
\text { trayek pengumpan }\end{array}$ & 100 & 368 \\
\hline & Tarif & 100 & 355 \\
\hline \multirow{3}{*}{$\begin{array}{l}\text { Kesetara } \\
\text { an }\end{array}$} & Kursi prioritas & 357 & 332 \\
\hline & $\begin{array}{l}\text { Ruang khusus untuk } \\
\text { kursi roda }\end{array}$ & 202 & 358 \\
\hline & $\begin{array}{l}\text { Kemiringan lantai } \\
\text { dan tekstur khusus }\end{array}$ & 329 & 325 \\
\hline \multirow{5}{*}{$\begin{array}{l}\text { Keteratu } \\
\text { ran }\end{array}$} & Waktu tunggu & 230 & 358 \\
\hline & $\begin{array}{l}\text { Kecepatan } \\
\text { perjalanan }\end{array}$ & 224 & 362 \\
\hline & Informasi pelayanan & 400 & 312 \\
\hline & $\begin{array}{l}\text { Informasi gangguan } \\
\text { perjalanan bus }\end{array}$ & 271 & 360 \\
\hline & $\begin{array}{l}\text { Ketepatan dan } \\
\text { kepastian jadwal } \\
\text { keberangkatan dan } \\
\text { kedatangan bus }\end{array}$ & 400 & 356 \\
\hline \multirow[t]{2}{*}{ Tangible } & Kerapian petugas & 390 & 352 \\
\hline & $\begin{array}{l}\text { Fasilitas kursi di tiap } \\
\text { halte tersedia }\end{array}$ & 200 & 367 \\
\hline Jumlah & & 7190 & 9487 \\
\hline
\end{tabular}

dan kepentingan untuk setiap variabel maupun secara keseluruhan pelayanan Trans Balikpapan. Adapun hasil 
perhitungan rata-rata kinerja dan kepentingan pelayanan Trans Balikpapan dapat dilihat pada Tabel 6.

Tabel 5.

Tingkat Kesesuaian Pelayanan Trans Balikpapan

\begin{tabular}{|c|c|c|c|}
\hline Faktor & Variabel & $\begin{array}{l}\text { Tingkat } \\
\text { Kesesuai } \\
\text { an }\end{array}$ & Keterangan \\
\hline \multirow[t]{7}{*}{$\begin{array}{l}\text { Kenyam } \\
\text { anan }\end{array}$} & $\begin{array}{l}\text { Kenyamanan tempat } \\
\text { duduk bus }\end{array}$ & $112 \%$ & Sangat Tidak Puas \\
\hline & Kapasitas bus & $111 \%$ & Sangat Tidak Puas \\
\hline & $\begin{array}{l}\text { Fasilitas pengatur } \\
\text { suhu ruangan bus }\end{array}$ & $54 \%$ & Sangat Tidak Puas \\
\hline & $\begin{array}{l}\text { Fasilitas kebersihan } \\
\text { bus }\end{array}$ & $118 \%$ & Sangat Tidak Puas \\
\hline & $\begin{array}{l}\text { Luas lantai per orang } \\
\text { halte }\end{array}$ & $27 \%$ & Sangat Tidak Puas \\
\hline & $\begin{array}{l}\text { Fasilitas kebersihan } \\
\text { halte }\end{array}$ & $115 \%$ & Sangat Tidak Puas \\
\hline & $\begin{array}{l}\text { Fasilitas kemudahan } \\
\text { naik/ turun } \\
\text { kendaraan }\end{array}$ & $76 \%$ & Sangat Tidak Puas \\
\hline \multirow[t]{4}{*}{$\begin{array}{l}\text { Keselam } \\
\text { atan }\end{array}$} & $\begin{array}{l}\text { Keselamatan di } \\
\text { tempat } \\
\text { pemberhentian }\end{array}$ & $100 \%$ & Sangat Tidak Puas \\
\hline & Kelaikan kendaraan & $87 \%$ & Sangat Tidak Puas \\
\hline & $\begin{array}{l}\text { Peralatan } \\
\text { keselamatan }\end{array}$ & $93 \%$ & Sangat Tidak Puas \\
\hline & $\begin{array}{lr}\text { Fasilitas } & \text { pegangan } \\
\text { bagi } & \text { penumpang } \\
\text { berdiri } & \end{array}$ & $29 \%$ & Sangat Tidak Puas \\
\hline Empati & $\begin{array}{l}\text { Ketersediaan } \\
\text { Layanan Pengaduan }\end{array}$ & $111 \%$ & Sangat Tidak Puas \\
\hline \multirow{4}{*}{$\begin{array}{l}\text { Keaman } \\
\text { an }\end{array}$} & Identitas kendaraan & $30 \%$ & Sangat Tidak Puas \\
\hline & $\begin{array}{l}\text { Tanda pengenal } \\
\text { pengemudi }\end{array}$ & $59 \%$ & Sangat Tidak Puas \\
\hline & $\begin{array}{l}\text { Petugas keamanan } \\
\text { bus }\end{array}$ & $42 \%$ & Sangat Tidak Puas \\
\hline & $\begin{array}{l}\text { Petugas keamanan } \\
\text { halte }\end{array}$ & $101 \%$ & Sangat Tidak Puas \\
\hline \multirow[t]{2}{*}{$\begin{array}{l}\text { Keterjan } \\
\text { gkauan }\end{array}$} & $\begin{array}{l}\text { Integrasi jaringan } \\
\text { trayek pengumpan }\end{array}$ & $27 \%$ & Sangat Tidak Puas \\
\hline & Tarif & $28 \%$ & Sangat Tidak Puas \\
\hline \multirow{3}{*}{$\begin{array}{l}\text { Kesetara } \\
\text { an }\end{array}$} & Kursi prioritas & $108 \%$ & Sangat Tidak Puas \\
\hline & $\begin{array}{l}\text { Ruang khusus untuk } \\
\text { kursi roda }\end{array}$ & $56 \%$ & Sangat Tidak Puas \\
\hline & $\begin{array}{l}\text { Kemiringan lantai } \\
\text { dan tekstur khusus }\end{array}$ & $101 \%$ & Sangat Tidak Puas \\
\hline \multirow{5}{*}{$\begin{array}{l}\text { Keteratu } \\
\text { ran }\end{array}$} & Waktu tunggu & $64 \%$ & Sangat Tidak Puas \\
\hline & $\begin{array}{l}\text { Kecepatan } \\
\text { perjalanan }\end{array}$ & $62 \%$ & Sangat Tidak Puas \\
\hline & Informasi pelayanan & $128 \%$ & Tidak Puas \\
\hline & $\begin{array}{l}\text { Informasi gangguan } \\
\text { perjalanan bus }\end{array}$ & $75 \%$ & Sangat Tidak Puas \\
\hline & $\begin{array}{lr}\text { Ketepatan dan } \\
\text { kepastian jadwal } \\
\text { keberangkatan dan } \\
\text { kedatangan bus }\end{array}$ & $112 \%$ & Sangat Tidak Puas \\
\hline \multirow[t]{2}{*}{ Tangible } & Kerapian petugas & $111 \%$ & Sangat Tidak Puas \\
\hline & $\begin{array}{l}\text { Fasilitas kursi di tiap } \\
\text { halte tersedia }\end{array}$ & $54 \%$ & Sangat Tidak Puas \\
\hline Jumlah & & $76 \%$ & - \\
\hline Rata-rata & & $76 \%$ & Sangat Tidak Puas \\
\hline
\end{tabular}

Beráasarkan Tabei 6 diketanui banwa variabei đengan kinerja tertinggi berdasarkan pendapat penumpang adalah faktor kenyamanan meliputi kenyamanan tempat duduk bus dan fasilitas kemudahan naik/ turun kendaraan, faktor keamanan meliputi identitas kendaraan dan faktor tangible yaitu kerapian petugas dengan nilai 4,00. Dimana nilai ini merupakan nilai maksimal yang diperoleh suatu variabel, artinya bahwa kinerja variabel ini tergolong sangat baik berdasarkan persepsi penumpang. Namun terdapat pula variabel dengan kinerja terendah, yaitu faktor kenyamanan meliputi fasilitas kebersihan halte, faktor empati meliputi layanan pengaduan, faktor keamanan meliputi Tanda pengenal pengemudi, faktor kesetaraan meliputi kursi prioritas dan ruang khusus untuk kursi roda dengan nilai 1,00 . Kemudian terdapat variabel dengan kepentingan tertinggi yaitu faktor kesetaraan meliputi kursi prioritas dengan nilai 3,68. Sehingga dapat disimpulkan bahwa kursi prioritas merupakan variabel yang ketersediaannya paling penting dibandingkan variabel lainnya dalam menunjang pelayanan Trans Balikpapan. Namun terdapat pula variabel dengan kepentingan paling rendah menurut pendapat penumpang yaitu kerapian petugas dari faktor tangible dengan nilai 3,12. Dimana hal ini dapat disimpulkan bahwa penumpang Trans Balikpapan menganggap kerapian petugas atau kelengkapan seragam petugas tergolong kurang penting dibandingkan variabel lainnya dalam menunjang pelayanan Trans Balikpapan.

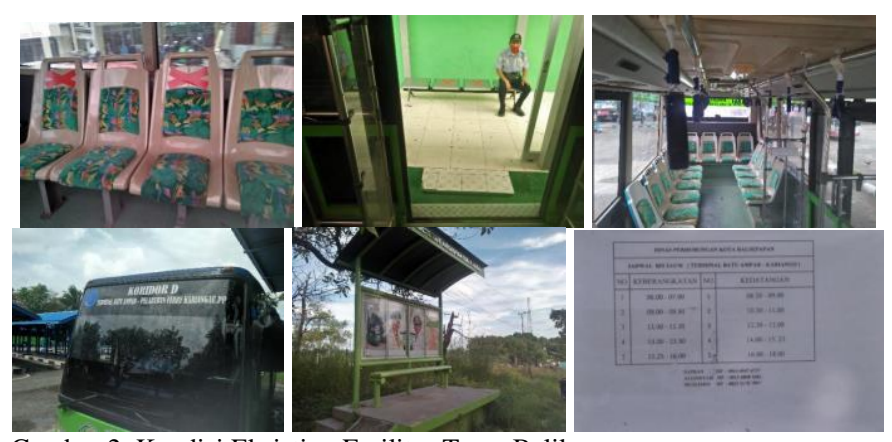

Gambar 2. Kondisi Eksisting Fasilitas Trans Balikpapan

\section{E. Pemetaan Kuadran}

Dari hasil perhitungan rata-rata kinerja dan kepentingan selanjutnya dilakukan pemetaan kuadran menggunakan hasil perhitungan tersebut. Dengan melakukan pemetaan kuadran, diketahui variabel yang termasuk dalam Kuadran I, Kuadran II, Kuadran III dan Kuadran IV. Pemetaan kuadran terhadap variabel pelayanan Trans Balikpapan dapat dilihat pada Gambar 3.

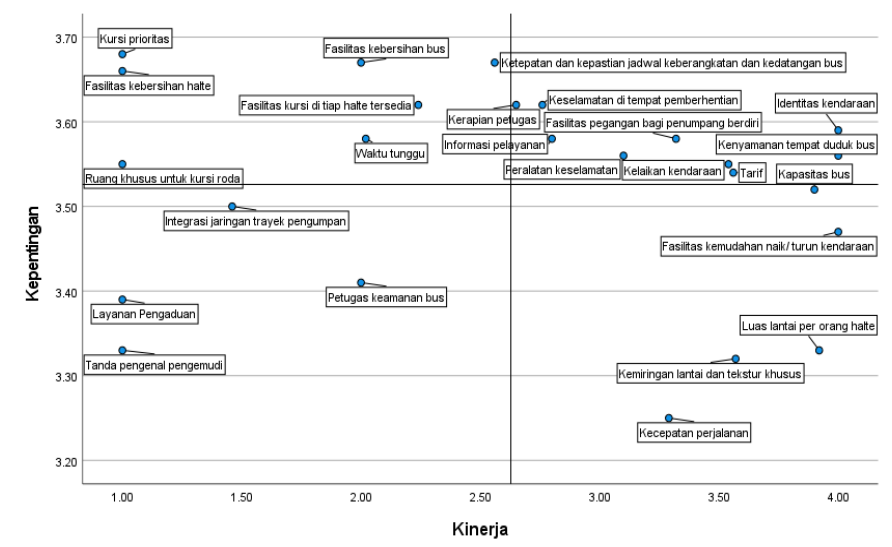

Gambar 3. Pemetaan Kuadran Variabel Pelayanan Trans Balikpapan 1. Kuadran I (Prioritas Utama) 
Kuadran ini memuat variabel yang dianggap penting namun kinerjanya belum sesuai dengan yang diharapkan oleh pengguna jasa. Adapun yang termasuk dalam kuadran ini terdiri dari faktor kesetaraan meliputi kursi prioritas dan ruang khusus untuk kursi roda, faktor kenyamanan terdiri dari fasilitas kebersihan halte, fasilitas kebersihan bus dan faktor keteraturan terdiri dari ketepatan waktu dan waktu tunggu. Berdasarkan survei primer, diketahui bahwa sebagian besar penumpang Trans Balikpapan atau sebesar 68\% merupakan perempuan yang menggunakan Trans Balikpapan dikarenakan tidak mampu menggunakan atau tidak mempunyai kendaraan. Selain itu sebagian penumpang Trans Balikpapan, atau sebanyak $2 \%$ berusia 56 tahun. Mengingat Trans Balikpapan mengalami waktu puncak ketika jam keberangkatan dan kedatangan pelajar dimana hampir seluruh tempat duduk terisi, ketersediaan tempat duduk prioritas dianggap penting oleh sebagian penumpang.

2. Kuadran II (Pertahankan Posisi)

Variabel yang termasuk dalam kuadran ini merupakan variabel yang dianggap penting dan memiliki kinerja yang sesuai dengan harapan penumpang. Adapun yang termasuk dalam kuadran ini yaitu faktor keselamatan meliputi keselamatan di tempat pemberhentian, faktor tangible meliputi fasilitas kursi di tiap halte tersedia, faktor keselamatan meliputi fasilitas pegangan bagi penumpang berdiri, kelaikan kendaraan dan Peralatan keselamatan, faktor keteraturan meliputi informasi pelayanan dan identitas kendaraan, faktor keterjangkauan meliputi Tarif, faktor kenyamanan meliputi kenyamanan tempat duduk bus, kapasitas kendaraan.

\section{Kuadran III (Prioritas Rendah)}

Adapun kuadran III berisi variabel yang dianggap kurang penting serta memiliki kinerja dibawah harapan penumpang. Adapun yang termasuk dalam kuadran ini terdiri dari faktor keterjangkauan meliputi Integrasi jaringan trayek pengumpan, faktor empati meliputi layanan pengaduan, faktor keamanan meliputi Tanda pengenal pengemudi dan petugas keamanan bus.

4. Kuadran IV (Berlebihan).

Adapun Kuadran IV berisi variabel yang dianggap kurang penting namun memiliki kinerja diatas harapan penumpang. Adapun yang termasuk dalam kuadran ini terdiri dari faktor tangible kerapian petugas, faktor keteraturan meliputi kecepatan perjalanan, faktor kesetaraan meliputi kemiringan lantai dan tekstur khusus, faktor kenyamanan meliputi Luas lantai per orang halte dan kemudahan naik-turun kendaraan.

\section{KESIMPULAN/RINGKASAN}

Berdasarkan hasil analisis tingkat kesesuaian, secara rata-rata keseluruhan pelayanan Trans Balikpapan termasuk dalam kategori kurang puas menurut penumpang dengan nilai $76 \%$. Berdasarkan perhitungan nilai rata-rata kinerja dan kepentingan, diketahui bahwa variabel dengan kinerja tertinggi berdasarkan pendapat penumpang adalah faktor kenyamanan meliputi kenyamanan tempat duduk bus dan fasilitas kemudahan naik/ turun kendaraan, faktor keamanan meliputi identitas kendaraan dan faktor tangible yaitu kerapian petugas dengan nilai 4,00. Terdapat variabel dengan kepentingan tertinggi yaitu faktor kesetaraan meliputi kursi prioritas dengan nilai 3,68. Berdasarkan pemetaan kuadran, didapatkan variabel yang termasuk dalam Kuadran I atau prioritas utama terdiri dari faktor kesetaraan meliputi kursi prioritas dan ruang khusus

Tabel 6.

Rata-Rata Tingkat Kinerja dan Kepentingan Pelayanan Trans Balikpapan

\begin{tabular}{|c|c|c|c|}
\hline \multirow[t]{2}{*}{ Faktor } & \multirow[t]{2}{*}{ Variabel } & \multicolumn{2}{|c|}{ Rata-rata } \\
\hline & & $\begin{array}{l}\text { Kinerja (Xi } \\
\text { Rata-Rata) }\end{array}$ & $\begin{array}{l}\text { Kinerja }(\mathrm{Xi} \\
\text { Rata-Rata) }\end{array}$ \\
\hline \multirow[t]{7}{*}{$\begin{array}{l}\text { Kenyam } \\
\text { anan }\end{array}$} & $\begin{array}{l}\text { Kenyamanan tempat } \\
\text { duduk bus }\end{array}$ & 4,00 & 3,56 \\
\hline & Kapasitas bus & 3,90 & 3,52 \\
\hline & $\begin{array}{l}\text { Fasilitas pengatur } \\
\text { suhu ruangan bus }\end{array}$ & 2,00 & 3,67 \\
\hline & $\begin{array}{l}\text { Fasilitas kebersihan } \\
\text { bus }\end{array}$ & 3,92 & 3,33 \\
\hline & $\begin{array}{l}\text { Luas lantai per orang } \\
\text { halte }\end{array}$ & 1,00 & 3,66 \\
\hline & $\begin{array}{l}\text { Fasilitas kebersihan } \\
\text { halte }\end{array}$ & 4,00 & 3,47 \\
\hline & $\begin{array}{l}\text { Fasilitas kemudahan } \\
\text { naik/ turun } \\
\text { kendaraan }\end{array}$ & 2,76 & 3,62 \\
\hline \multirow[t]{4}{*}{$\begin{array}{l}\text { Keselam } \\
\text { atan }\end{array}$} & $\begin{array}{l}\text { Keselamatan di } \\
\text { tempat } \\
\text { pemberhentian }\end{array}$ & 3,54 & 3,55 \\
\hline & Kelaikan kendaraan & 3,10 & 3,56 \\
\hline & $\begin{array}{l}\text { Peralatan } \\
\text { keselamatan }\end{array}$ & 3,32 & 3,58 \\
\hline & $\begin{array}{lr}\text { Fasilitas pegangan } \\
\text { bagi } & \text { penumpang } \\
\text { berdiri } & \end{array}$ & 1,00 & 3,39 \\
\hline Empati & $\begin{array}{l}\text { Ketersediaan } \\
\text { Layanan Pengaduan }\end{array}$ & 4,00 & 3,59 \\
\hline \multirow{4}{*}{$\begin{array}{l}\text { Keaman } \\
\text { an }\end{array}$} & Identitas kendaraan & 1,00 & 3,33 \\
\hline & $\begin{array}{l}\text { Tanda pengenal } \\
\text { pengemudi }\end{array}$ & 2,00 & 3,41 \\
\hline & $\begin{array}{l}\text { Petugas keamanan } \\
\text { bus }\end{array}$ & 1,46 & 3,50 \\
\hline & $\begin{array}{l}\text { Petugas keamanan } \\
\text { halte }\end{array}$ & 3,56 & 3,54 \\
\hline \multirow[t]{2}{*}{$\begin{array}{l}\text { Keterjan } \\
\text { gkauan }\end{array}$} & $\begin{array}{l}\text { Integrasi jaringan } \\
\text { trayek pengumpan }\end{array}$ & 1,00 & 3,68 \\
\hline & Tarif & 1,00 & 3,55 \\
\hline \multirow{3}{*}{$\begin{array}{l}\text { Kesetara } \\
\text { an }\end{array}$} & Kursi prioritas & 3,57 & 3,32 \\
\hline & $\begin{array}{l}\text { Ruang khusus untuk } \\
\text { kursi roda }\end{array}$ & 2,02 & 3,58 \\
\hline & $\begin{array}{l}\text { Kemiringan lantai } \\
\text { dan tekstur khusus }\end{array}$ & 3,29 & 3,25 \\
\hline \multirow{5}{*}{$\begin{array}{l}\text { Keteratu } \\
\text { ran }\end{array}$} & Waktu tunggu & 2,30 & 3,58 \\
\hline & $\begin{array}{l}\text { Kecepatan } \\
\text { perjalanan }\end{array}$ & 2,24 & 3,62 \\
\hline & Informasi pelayanan & 4,00 & 3,12 \\
\hline & $\begin{array}{l}\text { Informasi gangguan } \\
\text { perjalanan bus }\end{array}$ & 2,71 & 3,60 \\
\hline & $\begin{array}{l}\text { Ketepatan dan } \\
\text { kepastian jadwal } \\
\text { keberangkatan dan } \\
\text { kedatangan bus }\end{array}$ & 4,00 & 3,56 \\
\hline \multirow[t]{2}{*}{ Tangible } & Kerapian petugas & 3,90 & 3,52 \\
\hline & $\begin{array}{l}\text { Fasilitas kursi di tiap } \\
\text { halte tersedia }\end{array}$ & 2,00 & 3,67 \\
\hline Jumlah & & 72,40 & 72,40 \\
\hline
\end{tabular}

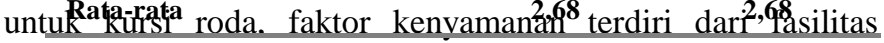
kebersihan halte, fasilitas kebersihan bus dan faktor keteraturan terdiri dari ketepatan waktu dan waktu tunggu. Kemudian 
variabel yang termasuk dalam Kuadran II yaitu faktor

keselamatan meliputi keselamatan di tempat pemberhentian, faktor tangible meliputi fasilitas kursi di tiap halte tersedia, faktor keselamatan meliputi fasilitas pegangan bagi penumpang berdiri, kelaikan kendaraan dan Peralatan keselamatan, faktor keteraturan meliputi informasi pelayanan dan identitas kendaraan, faktor keterjangkauan meliputi Tarif, faktor kenyamanan meliputi kenyamanan tempat duduk bus, kapasitas kendaraan. Terdapat variabel yang termasuk dalam Kuadran III atau prioritas rendah yaitu faktor keterjangkauan meliputi Integrasi jaringan trayek pengumpan, faktor empati meliputi layanan pengaduan, faktor keamanan meliputi Tanda pengenal pengemudi dan petugas keamanan bus. Adapun variabel yang termasuk dalam Kuadran IV atau berlebihan terdiri dari faktor tangible meliputi kerapian petugas, faktor keteraturan meliputi kecepatan perjalanan, faktor kesetaraan meliputi kemiringan lantai dan tekstur khusus, faktor kenyamanan meliputi Luas lantai per orang halte dan kemudahan naik-turun kendaraan. Rekomendasi bagi Dinas Perhubungan Kota Balikpapan adalah melakukan perbaikan sarana yang mengalami kerusakan dan penyediaan sarana yang dapat menunjang pelayanan Trans Balikpapan, khususnya dengan mempertimbangkan pendapat pengguna.

\section{UCAPAN TERIMA KASIH}

Penulis Z.S. mengucapkan terima kasih kepada Ibu Ajeng Nugrahaning Dewanti, S.T., M.T., M.Sc. dan Bapak Mohtana Kharisma Kadri S.T., M.Eng atas kesediaannya membimbing peneliti hingga mampu menyelesaikan tugas akhir. Penulis juga mengucapkan terima kasih kepada pihak-pihak yang berkenan menjadi responden penelitian ini.

\section{DAFTAR PUSTAKA}

[1] W. Winarni, E. R. Pratiwi, and S. Subchan, "Desain Rute Jaringan Moda Bus Kota di Balikpapan sebagai Antisipasi Kemacetan di Balikpapan," SPECTA J. Technol., 2018, doi: 10.35718/specta.v2i3.39.

[2] M. Simanjuntak, A. Gunawan Malau, and T. J. Frans Kalangie, "Kajian Tingkat Kebutuhan Kompetensi Berdasarkan Permenhub No. PM 7 Tahun 2018 Tentang Rencana Induk Pengembangan SKKNI Sektor Transportasi," Meteor STIP Marunda, 2019, doi: 10.36101/msm.v12i1.57.

[3] R. A. Chikita, L. Djakfar, and M. R. Anwar, "Kajian Kinerja Terminal Batu Ampar Kota Balikpapan," Rekayasa Sipil, 2017, doi: 10.21776/ub.rekayasasipil/2017.011.02.7.

[4] Y. Octaviana, "Studi Tentang Pengelolaan Terminas Bus Antar Kota Dalam Provinsi di Kota Balikpapan," eJournal Ilmu Pemerintah., 2017.

[5] S. of tranportation Statistics-BPS, "Land Transportation Statistics," 2018.

[6] BPS RI, "Statistik Transportasi Darat," Bps Ri. 2017.

[7] S. Jamieson, "Likert scales: How to (ab)use them," Med. Educ., vol. 38, no. 12, pp. 1217-1218, 2004, doi: 10.1111/j.1365-2929.2004.02012.x.

[8] R. W. Emerson, "Likert Scales," J. Vis. Impair. Blind., 2017, doi: 10.1177/0145482x1711100511.

[9] L. Anggraeni, P. Deoranto, \& D. Ikasari, "Analisis Persepsi Konsumen Menggunakan Metode Importance Performance Analysis Dan Customer Satisfaction Index". Industria: Jurnal Teknologi Dan Manajemen Agroindustri, Vol. Nomor 2, (2016) 74-81,

[10] Y. S. Saputra dan S. W. Hati, "Analisis Kepuasan Pelanggan Terhadapkualitas Layanan Ojek Online (Wakjek) Di Kota Batam"., Journal of Applied Business Administration, Vol. 1, No. 1, (2017, Maret) 